\title{
Percutaneous Treatment Options of Lower Urinary Tract Fistulas and Leakages
}

\section{Perkutane Therapieoptionen von Fisteln und Leckagen der ableitenden Harnwege}

Authors

Daniel Kuetting, Claus Christian Pieper

Affiliation

Department of Radiology, University Hospital, Bonn, Germany

Key words

ureteral fistulas, ureteral leakages, transrenal ureteral

embolization, minimally invasive fistula treatment

received 07.12 .2017

accepted 15.02.2018

Bibliography

DOI https://doi.org/10.1055/a-0581-5533

Published online: 2018

Fortschr Röntgenstr 2018; 190: 692-700

(c) Georg Thieme Verlag KG, Stuttgart · New York

ISSN 1438-9029

Correspondence

Priv.-Doz. Dr. Claus Christian Pieper

Department of Radiology, University Hospital,

Sigmund-Freund-Strasse 25, 53105 Bonn, Germany

Tel.: ++ 49/2 28/28715960

Fax: $++49 / 228 / 28715598$

claus.christian.pieper@ukb.uni-bonn.de

\section{ZUSAMMENFASSUNG}

Hintergrund Fisteln des unteren Harntrakts sind seltene Erkrankungen die häufig mit einer beträchtlichen Morbidität einhergehen. Die Behandlung solcher Fisteln oder Leckagen ist technisch anspruchsvoll und stellt eine interdisziplinäre Herausforderung dar. Insbesondere bei Fisteln, die durch Tumoren verursacht werden oder nach Strahlentherapie auftreten ist die Erfolgsquote chirurgischer Verfahren limitiert. Des Weitern schließen schwere Komorbiditäten in diesem Patientengut häufig operative Eingriffe aus, sodass alternativ perkutane Behandlungsansätze als weniger invasive Behandlungsoption in Frage kommen.

Methode Diese Übersicht basiert auf Fallserien und Fallberichten zur perkutanen Behandlung von Fisteln und Leckagen des unteren Harntrakts aus den letzten vier Jahrzehnten (1979 - 2017). Berücksichtigte Methoden waren dabei Ureterfulguration, Gewebeklebstoff-basierte Embolisation, nicht-ablösbare und ablösbare Ballons, Ureterclipping, Uretercoiling, Silikon und Nylon Plugs sowie modifizierte Vascular Plugs.
Ergebnisse und Schlussfolgerung Perkutane Behandlungsmöglichkeiten von Fisteln und Leckagen des unteren Harntrakts ermöglichen eine entweder temporäre oder dauerhafte, instantane Ureterokklusion. Die transrenale Ureterokklusion ist im Allgemeinen eine sichere und zuverlässige Alternative zur operativen Sanierung von Ureterfisteln und -leckagen. Bisher hat sich keine Technik als überlegen erwiesen. Abhängig von der zugrundeliegenden Erkrankung kann die optimale Therapieoption variieren. Die Therapie sollte den individuellen Bedürfnissen der Patienten entsprechend angepasst werden.

\section{Kernaussagen}

- Patienten mit therapierefraktären Ureterfisteln/Ureterleckagen können von der transrenalen Ureterokklusion profitieren.

- Die transrenale Ureterokklusion ermöglicht langfristige Symptomlinderung.

- Interventionelle Radiologen sollten mit den gängigen Techniken der transrenalen Ureterokklusion vertraut sein.

ABSTRACT

Background Lower urinary tract fistulas are currently a rather rare, but severe condition associated with considerable morbidity. Treatment is challenging, especially in fistulas caused by pelvic malignancy or radiation therapy. Surgical treatment attempts fail in a considerable number of patients, especially in those with pelvic malignancies/prior radiation therapy or are precluded altogether due to severe comorbidity. For such patients percutaneous approaches can provide alternative treatment.

Method This review is based on case studies and case reports dealing with percutaneous treatment options of lower urinary tract fistulas and leakages from the past four decades (1979-2017). The included techniques were ureteral fulguration, tissue adhesive-based embolization, non-detachable and detachable balloon occlusion, ureteral coiling, ureteral clipping, silicone or nylon plug as well as modified vascular plug embolization.

Results and Conclusion Percutaneous treatment options of lower urinary tract fistulas and leakages allow for either permanent or temporary, instant ureteral occlusion. In general, transrenal ureteral occlusion is a safe and reliable alternative to surgical treatment of ureteral fistulas and leakages. 
So far, no technique has been proven to be superior to the others. Depending on the underlying disease, the optimal percutaneous technique may vary and should be chosen according to the individual needs of the patients.

\section{Key Points}

- Patients with therapy-refractory urerteral fistulas may benefit from transrenal ureteral occlusion.
- Transrenal ureteral occlusion allows for long-term symptom relief.

- Ureteral occlusion should be in the armamentarium of interventional radiologists.

\section{Citation Format}

- Kuetting D, Pieper CC . Percutaneous Treatment Options of Lower Urinary Tract Fistulas and Leakages. Fortschr Röntgenstr 2018; 190: 692-700

\section{Introduction}

Lower urinary tract fistulas and leakages are currently rather rare entities. However, especially when associated with advanced pelvic malignancy, they are associated with severe morbidity. Ureteral stent placement with or without additional urinary diversion by nephrostomy remains the first therapeutic option in such cases, but frequently does not suffice to completely eliminate urinary flow, so that further treatment may be necessary. Particularly in patients with pelvic cancer, poor general condition and tissue injury due to radiation therapy, surgical therapy is often very challenging and associated with a high perioperative risk. In such patients minimally invasive techniques offer alternative temporary or permanent treatment [1]. Although a wide variety of interventional treatment options of lower urinary tract fistulas have been performed for almost 40 years, there are neither prospective randomized studies nor guidelines dealing with the optimal treatment strategy. This review intends to cover the relevant diagnostic workup as well as available interventional therapeutic options of ureteral fistulas.

\section{Ureteral anatomy and physiology}

When planning a ureteral intervention, it is important to consider the anatomy and physiology of the ureters, especially changes that occur when the ureter is subjected to outflow obstruction. The ureter, a retroperitoneal tube-like structure, connects the renal pelvis and the urinary bladder. The ureters run anterior along the psoas muscle into the pelvis where they cross the common iliac artery and vein before they enter the bladder. The ureters have a close anatomical relationship to several pelvic structures and can therefore be involved in adjacent pathological processes. The right ureter runs adjacent to the terminal ileum, cecum, appendix and the ascending colon, while the left ureter borders the descending colon and the sigmoid colon. In the female pelvis both ureters adjoin the cervix. The ureters typically measure $25-30 \mathrm{~cm}$ in length and $3-4 \mathrm{~mm}$ in diameter.

In case of urinary reflux or obstruction, the diameter of the ureter and the renal pelvis as well as intraluminal pressure levels can increase considerably. Results of a porcine in-vivo study showed that normal intra-pelvic and ureteral pressure is typically lower than $14 \mathrm{cmH}_{2} \mathrm{O}$, while complete subpelvic occlusion may cause pressure peaks of up to $95 \mathrm{cmH}_{2} \mathrm{O}$ [2].

\section{Ureteral leakages / fistulas}

Ureteral fistulas can be subclassified into internal and external, as well as vascular and non-vascular fistulas. While internal ureteral fistulas are pathological communications with any of the adjacent hollow organs (i. e., ureterouterine, ureterovaginal and ureteroenteral), external ureteral fistulas are abnormal communications between the ureter and the skin. The most common cause of nonvascular lower urinary tract fistulas in high income countries is gynecological surgery, accounting for over $80 \%$ of genitourinary fistulas in women $[3,4]$. Urinary fistulas may also result from obstetric procedures $(8 \%)$, radiation therapy (6\%), trauma (4\%), surgical treatment or brachytherapy of prostate cancer $(0.3-4 \%)$, inflammatory processes, such as diverticulitis and pelvic malignancies [5, 6].

Internal ureteral fistulas are a possible source of severe morbidity as they may lead to urinoma or abscess formation. External ureteral fistulas, although usually less dangerous than internal fistulas, can cause skin irritations, impede hygiene and thus can be disabling and a source of social marginalization and the cause of depression [7].

Vascular ureteral fistulas can either be a result of aneurysmatic disease, abdominal surgery, radiation therapy or malignancies. Vascular ureteral fistulas are not the subject of this review and are described in detail elsewhere [8].

\section{Diagnostics}

The first step when a urinary fistula is suspected (e.g. urine discharge from the vagina) is determination of the relevant clinical history (known malignancy, previous surgery, radiation therapy, cesarean section). A large percentage of fistulas can be detected during rectovaginal examination as vesicovaginal or ureterovaginal fistulas are the most prevalent [1]. Cystoscopy or retrograde pyelography can additionally be performed at the discretion of the attending gynecologist/urologist. If clinical examinations do not reveal the location of the fistula, ureteral or vesical application of dye (e.g. methylene blue) or further imaging techniques are indicated.

Especially for adequate treatment planning, precise imaging is necessary to determine the exact location of the fistula and to delineate the relevant anatomy. Excretory urography, retrograde urography, and cutaneous fistulography all allow for diagnosis of ureteral fistulas with varying detection rates. Conventional intravenous urography for example is known to have a sensitivity for the detection of fistulas as low as 33 \% [9]. Although both CT and 

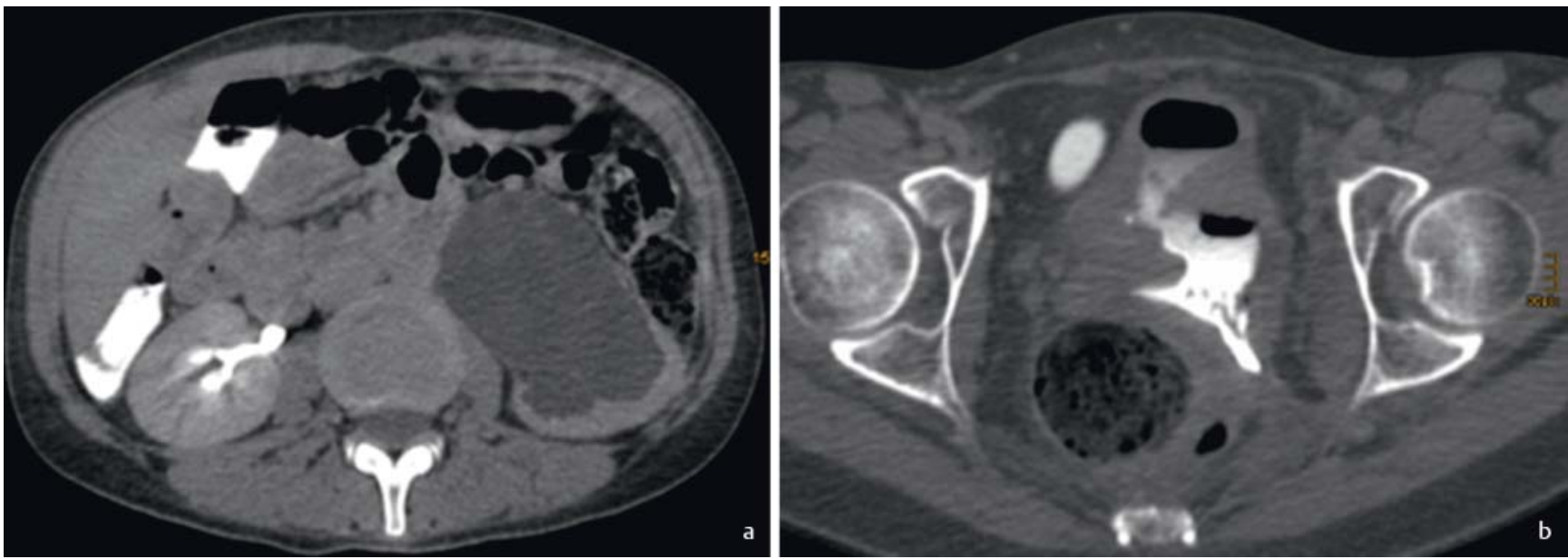

- Fig. 1 Axial CT slices in the renal excretory phase of a 31-year-old female patient with previously undiagnosed advanced cervical cancer. The patient became symptomatic with left-sided abdominal pain and urinary discharge from the vagina. The CT scan showed severe urinary stasis on the left with reduced contrast medium excretion of the left kidney a as well as a large vesicovaginal fistula $\mathbf{b}$.

- Abb. 1 Axiale CT Schnitte in der renalen Ausscheidungsphase einer 31 jährigen Patientin mit zuvor unbekanntem fortgeschrittenem Zervixkarzinom. Die Patientin wurde durch linksseitige Bauchschmerzen und Urinabgang über die Vagina symptomatisch. Das CT zeigt einen ausgeprägten Harnstau links mit reduzierter Kontrastmittelexkretion der linken Niere sowie eine große vesikovaginale Fistel.

MR urography are very sensitive for the detection of ureteral fistulas $[10,11]$, CT urography is currently the clinical standard for the evaluation of lower urinary tract fistulas ( $\vee$ Fig. 1 ).

\section{Treatment options}

Indications for adequate treatment should be discussed on an interdisciplinary basis (gynecologists, urologist, radiologists) depending on the cause and extent of the lower urinary tract fistula, as well as the patient's prognosis. For smaller ureteral fistulas, (retrograde) ureteral stenting and/or percutaneous nephrostomy tube placement may be attempted for $4-6$ weeks with a clinical success rate of approximately $50 \%$ for small, postoperative fistulas $[12,13]$. For larger ureteral fistulas, placement of a nephrostomy tube should also be performed to prevent infection, even if surgical or interventional treatment is necessary later [14].

Nephrostomy is usually performed by urologists under sonographic and fluoroscopic guidance, but can also be performed under CT guidance [15]. Usually the renal pelvis is punctured from a dorsolateral angle of $50-60^{\circ}$, so that the puncture tract runs through a relatively avascular area of the renal parenchyma between the anterior and posterior segmental branches of the renal artery (line of Brödel). After intubation of the ureter with a guidewire and sequential dilatation of the tract, a nephrostomy tube can be inserted (single stick technique). In cases of fistulas, the renal pelvis is often not dilated, making nephrostomy more challenging. In such cases initial puncture of the renal pelvis with a fine needle and subsequent contrast injection can be performed to facilitate a secondary dorsolateral puncture along the line of Brödel (double stick technique) ( $\triangleright$ Fig. 2). Alternatively, puncture may be facilitated by intravenous injection of contrast agent and diuretics.
Fistulas not responsive to percutaneous drainage therapy may require surgical or endovascular therapy. Surgical repair, which is typically performed after local inflammation has resolved (duration may vary substantially), includes excision of the fistulous tract and interposition of healthy tissue (e. g. omentum or muscle flap) or transureteroureterostomy. However, reconstructive therapy fails in up to $35 \%$ of cases and is mainly reserved for non-malignant postoperative and traumatic fistulas.

In patients with fistulas occurring after radiotherapy of malignant pelvic tumors, surgical treatment is technically even more demanding with lower rates of success, and higher rates of fistula recurrence $[1,16]$. Additionally, due to high morbidity and mortality rates, surgical ureteral reconstruction or diversion is not suitable for palliative patients with ureteral fistulas associated with extensive pelvic malignancies and a short life expectancy $[1,5,16]$.

Especially in these patients, treatment of urinary fistulas should be as minimally invasive as possible, easy to perform and permanent with the aim of increasing quality of life. In patients with a longer life expectancy, only temporary occlusion may be desirable. Several minimally invasive approaches ( $>$ Fig. 3 ) have been developed since the late $1970 \mathrm{~s}$ and should be performed according to the individual needs of the patient. The employed devices are usually used off-label. Maintaining a functioning nephrostomy after ureteral occlusion is imperative to avoid complications such as renal failure. Clinical results are summarized in > Table $\mathbf{1}$.

\section{Direct ureteral occlusion}

Direct ureteral occlusion procedures are more invasive than transrenal approaches and carry a larger risk of complications and therefore have not achieved wider clinical application. Percutaneous ureterostomy via a 34F retroperitoneal approach has been described in three patients. The ureter is transected to perform surgical ureterostomy of the proximal segment after mobilization. 

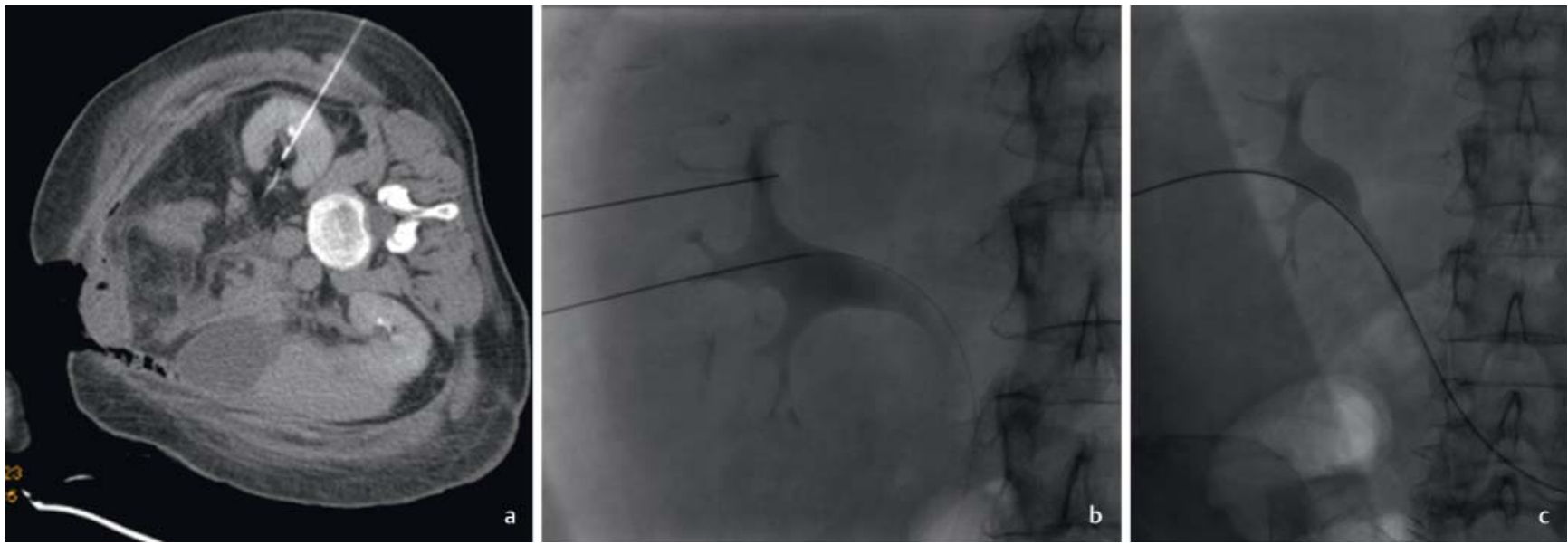

- Fig. 2 Nephrostomy of a non-dilated right kidney under CT and fluoroscopic guidance using the double stick technique. a CT-guided puncture of the right renal pelvis. b Contrast medium is injected via the needle placed under CT guidance (upper needle) to allow for fluoroscopically guided puncture of the renal pelvis in a position adequate for subsequent intubation of the ureter $\mathbf{c}$ and nephrostomy tube placement.

- Abb.2 Nephrostomie eines nicht dilatierten rechten Nierenbeckenkelchsystems unter CT- und Durchleuchtungskontrolle mit der "double stick“ Technik. a CT-gesteuerte Punktion des rechten Nierenbeckens. b Über die CT-gesteuert eingebrachte Nadel (obere Nadel) wird Kontrastmittel injiziert. Dies erleichtert die durchleuchtungsgesteurte Punktion des rechten Nierbenbeckens in einer Position, aus der der Ureter intubiert c und ein Nephrostoma angelegt werden kann.

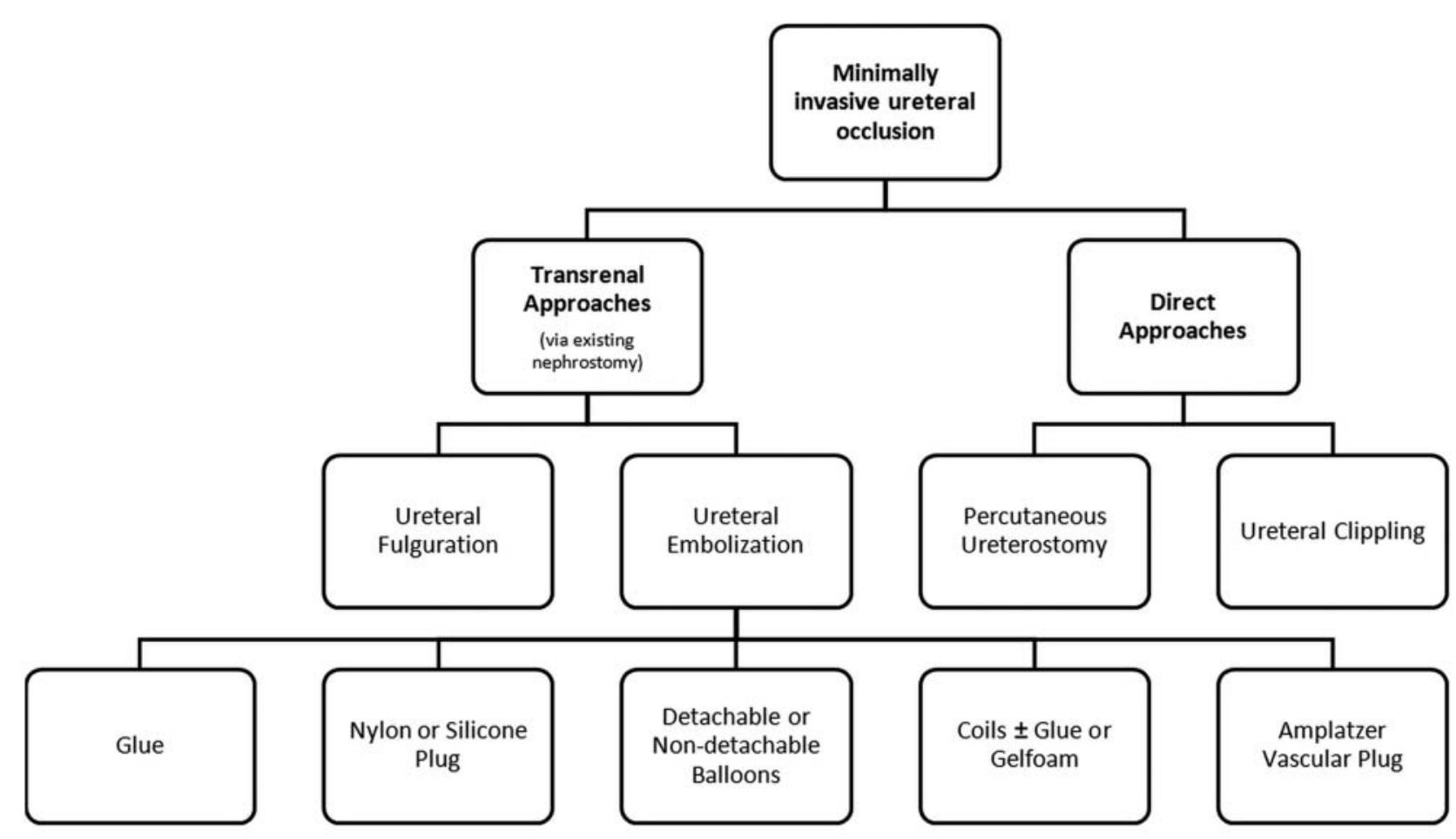

- Fig. 3 Available techniques for minimally invasive ureteral occlusion.

- Abb. 3 Verfügbare Techniken zur minimal invasiven Ureterokklusion.

This technique requires an endoscopically experienced urologist as well as a favorable ureteral anatomy [17].

Likewise, ureteral clipping that can successfully be performed via a $30 \mathrm{~F}$ sheath placed into the retroperitoneum [18-20] is not widely used today due to the time-consuming creation of the retroperitoneal access close to the vena cava or the aorta and possible necrosis of the ureteral wall. Furthermore, the clips that are required for this procedure are not commercially available. 
- Table 1 Overview of available treatment options, applicability and success rates.

\begin{tabular}{|c|c|c|c|c|c|c|c|}
\hline Technique & Study & $\begin{array}{l}\text { No. of } \\
\text { ureters }\end{array}$ & $\begin{array}{l}\text { Clinical } \\
\text { success } \\
\text { rate }^{*}\end{array}$ & $\begin{array}{l}\text { Mean or maximal } \\
\text { follow-up time } \\
\text { [months] }\end{array}$ & $\begin{array}{l}\text { Temporaryl } \\
\text { permanent } \\
\text { occlusion } \\
\text { possible? }\end{array}$ & $\begin{array}{l}\text { Clinical } \\
\text { use today }\end{array}$ & $\begin{array}{l}\text { Immediate } \\
\text { occlusion }\end{array}$ \\
\hline Clipping & $\begin{array}{l}\text { Cragg et al. } 1989 \\
\text { Farrell et al. } 1997\end{array}$ & 15 & $93 \%$ & $2-17$ & $P$ & No & Yes \\
\hline Fulguration & $\begin{array}{l}\text { Reddy et al. } 1987 \\
\text { Kopecky et al. } 1989\end{array}$ & 4 & $100 \%$ & $2.5-21$ & $\mathrm{P}$ & No & No \\
\hline Nylon plug & $\begin{array}{l}\text { Kinn et al. } 1986 \\
\text { Sanchez et al. } 1988\end{array}$ & 32 & $66 \%$ & 8 & $\mathrm{~T} / \mathrm{P}$ & No & Yes \\
\hline Silicon plug + NBCA & Schurawitzki et al. 1991 & 3 & $100 \%$ & 9.1 & $(\mathrm{~T}) / \mathrm{P}$ & No & Yes \\
\hline NBCA & $\begin{array}{l}\text { Günther et al. } 1979 \\
\text { Schild et al. } 1991\end{array}$ & $\begin{array}{l}3 \\
10\end{array}$ & $\begin{array}{l}100 \% \\
50 \%\end{array}$ & $\begin{array}{l}\text { NA } \\
3.6(0.25-38)\end{array}$ & $(\mathrm{T}) / \mathrm{P}$ & No & Yes \\
\hline $\begin{array}{l}\text { Non-detachable } \\
\text { balloons }\end{array}$ & $\begin{array}{l}\text { Papanicolaou et al. } 1985 \\
\text { Horenblas et al. } 2000\end{array}$ & $\begin{array}{l}3 \\
7\end{array}$ & $\begin{array}{l}100 \% \\
71 \%\end{array}$ & $\begin{array}{l}\text { Max. } 5 \\
\text { Max. } 5.5\end{array}$ & $\mathrm{~T}$ & No & Yes \\
\hline $\begin{array}{l}\text { Detachable balloons } \\
\text { (silicon) }\end{array}$ & Schild et al. 1994 & 52 & $69 \%$ & 8 & $\mathrm{~T} / \mathrm{P}$ & No & Yes \\
\hline $\begin{array}{l}\text { Detachabe balloons } \\
\text { (saline) }\end{array}$ & Franke et al. 2015 & 18 & $55 \%$ & 2.5 & $\mathrm{~T} / \mathrm{P}$ & Yes & Yes \\
\hline Coils + gelfoam & $\begin{array}{l}\text { Gaylord et al. } 1989 \text {, } \\
\text { Bing et al. } 1992 \\
\text { Farrell et al. } 1997, \\
\text { Shindel et al. } 2006 \\
\text { Asvadi et al. } 2015\end{array}$ & 141 & $97 \%$ & $0.5-29$ & $P$ & Yes & Yes \\
\hline Coils + NBCA & Schild et al. 1994 & 21 & $81 \%$ & 4 & $\mathrm{P}$ & Yes & Yes \\
\hline AVP + coils + NBCA & Pieper et al. 2014 & 5 & $100 \%$ & 7 & $\mathrm{P}$ & Yes & Yes \\
\hline$A V P+N B C A$ & $\begin{array}{l}\text { Shabrang et al. } 2012 \\
\text { Saad et al. } 2013, \\
\text { Grasso et al. } 2014\end{array}$ & 10 & $90 \%$ & $\max .14$ & $P$ & Yes & Yes \\
\hline Latex-covered AVP & Pieper et al. 2014 & 10 & $90 \%$ & 5.5 & $\mathrm{~T} / \mathrm{P}$ & Yes & Yes \\
\hline
\end{tabular}

\section{Transrenal Approaches}

\section{Ureteral Fulguration}

Reddy et al. (1987) and Kopecky et al. (1991) performed ureteral fulguration for treatment of large fistulas using a $5 \mathrm{~F}$ electrode that was passed into the ureter via a 20F nephrostomy sheath [21] or a custom 7F angioplasty catheter with a $4 \times 20 \mathrm{~mm}$ balloon covered with gold strips connected to an electrocautery unit [22]. Fulguration can only be applied for short durations, as it causes severe pain. Reddy treated 3 patients and achieved long-term ureteral occlusion in 2 cases (follow-up range: 6 - 12 weeks). In the third patient the ureteral fistula persisted following treatment. Kopecky treated one patient and achieved partial ureteral occlusion at one month follow-up. This technique carries severe disadvantages. First, the procedure is painful, meaning patients require high doses of sedatives and analgesics to tolerate fulguration. Second, ureteral occlusion due to formation of scar tissue after fulguration takes time to develop, which is not desirable in patients with only a short life expectancy. Third, secondary fistulas may develop at the fulguration site.

\section{Glue embolization (N-Butyl-2-Cyanoacrylate)}

Ureteral glue embolization was first described by Günther et al. in 1979 [23]. Since then it has been modified several times and combined with embolization devices such as coils or vascular plugs to increase efficacy $[24,25]$. The original report described ureteral embolization with a mixture of n-butyl-2-cyanoacrylate (NBCA), iodized oil and tantalum powder. Proximal spilling of the tissue adhesive was prevented by temporary proximal intra-ureteral balloon occlusion. Although the initial success rate was high, only $50 \%$ of treated ureters $(n=10)$ were still sealed at follow-up (mean: 3.6 months; range: $0.25-38$ months). Poor long-term results were attributed to the fact that NBCA softens and dissolves in contact with urine [26]. While this technique can be performed at a low price with excellent "positioning" of the glue 
without upsizing of the nephrostomy access, its major drawback is frequent ureteral recanalization necessitating re-interventions.

\section{Detachable and non-detachable occluding balloons}

Günther et al. (1982) [27, 28] and Papanicolaou et al. (1985) [29] reported on the use of detachable and non-detachable balloons for ureteral occlusion, respectively.

Originally, for deployment of detachable balloons, an $11 \mathrm{Fr}$ catheter with a sterile latex condom tightly knotted to the tip was placed in a position proximal to the leak. The condom was then filled with a mixture of silicone elastomer and silicone fluid. Schild et al. (1994) reported on the largest cohort of patients treated with this technique. At follow-up (mean: 7.9 months; range: $0.25-61$ months), lasting ureteral occlusion was seen in $69 \%$ of the treated cases $(n=52)$ [30]. The drawbacks of this method are the risk of the condom bursting during deployment, as well as the frequently observed secondary deflation and migration necessitating re-intervention [31]. Furthermore, not all components required for this intervention are currently commercially available.

Recently, Franke et al. (2015) revived this technique by employing a commercially available semi-compliant detachable latex balloon filled with saline solution. They described a high rate of technical success, but also frequent dislocations so that re-intervention was necessary in $6 / 16$ ureters (37.5\%). Clinical success was defined as healing of the fistula with possible antegrade urination and was achieved in $55 \%$ of patients (mean follow-up: 2.5 months) [32].

Non-detachable balloons (e. g. Fogarty catheter) are inserted into the ureter proximal to the leak parallel to the nephrostomy catheter. The balloon is then inflated to occlude the ureter. Both the nephrostomy catheter and the balloon catheter are then sewn to the skin. Of 3 treated patients described in the original publication, 2 died within 24 hours due to reasons unrelated to ureteral occlusion. No reoccurrence of ureteral leakage was seen in the third patient (follow-up: 5 months) [29].

Balloon occlusion in general offers the prospect of temporary ureteral occlusion. While (re-) positioning and removal of non-detachable balloons is technically simpler, the need for permanent externalization of two catheters (nephrostomy tube / non-detachable balloon catheter) can be more of a burden for patients and is associated with a higher risk of infection. Ureteral wall necrosis is theoretically possible, but has not been described in the pertinent literature. However, non-detachable balloons frequently require adjusting and repositioning due to dislocation [33].

\section{Nylon and silicone plugs}

Kinn et al. were the first to describe ureteral occlusion using plugs in 1986 [34]. A nylon plug was placed in the distal ureter via a 26F access. Polidocanol was injected proximally and distally to the plug to induce fibrosis. At an average follow-up period of 6 months, $87 \%$ of treated patients $(n=15)$ showed significant clinical improvement. However, plug migration was observed in $50 \%$ of patients. In 1991, Schurawitzki et al. described a modification of the plug technique and used a silicone plug instead of a nylon plug, which was deployed via a $24 \mathrm{~F}$ access. In order to pre- vent dislocation, tissue adhesive was instilled proximally to the plug. Neither reoccurrence of ureteral leaks nor plug migration was seen in any of the patients $(n=3)$ during follow-up (mean follow-up: 9.1 months). Although it yields high clinical success rates, the major drawback of this technique is the necessity of a large caliber access [26].

\section{Coils ( \pm gelfoam or glue)}

The use of coils to achieve ureteral occlusion with different adjunctive embolisates currently has the largest evidence base. Gaylord et al. were the first to report on the use of coils (Gianturco) and gelfoam to occlude ureters [35] in 1989. The intervention can be performed using small caliber catheters inserted via a nephrostomy. If possible, the distal tip of the catheter is placed in the ureterovesical junction. Rather than pushing the coil out of the catheter, which increases the risk of vesical embolization, the catheter is retracted over a coil-pusher to unsheath the loaded coil. Additionally gelfoam is placed in the distal ureter to achieve immediate ureteral occlusion, as the coil-induced fibrotic reaction can take several weeks to fully obliterate the ureteral lumen. Complications are usually limited to coil separation and migration. In the original report, total ureteral occlusion was achieved in all cases $(n=5)$, follow-up revealed no reoccurrence of ureteral flow (mean: 10.8 months; range: 3 - 22 months). In a larger series by Farrell et al. [16], long-term results of ureteral occlusion with this approach were similarly good. Reoccurrence of ureteral leak/fistula was not seen in any of the included patients $(n=34)$ during follow-up (range: 2 weeks to 29 months). Overall, ureteral occlusion with coils and gelfoam has been described in 141 ureters with a clinical success rate as high as $97 \%$ with a follow-up between 0.5 and 29 months [2, 16, 35 - 37]

Schild et al. described the alternative use of NBCA instead of gelfoam in 21 ureters and found a permanent occlusion after one intervention in $81 \%$ of ureters at a mean follow-up of 4 months ( Fig.4) [30].

\section{Amplatzer Vascular Plug}

Amplatzer vascular plugs (AVP) - which are approved for endovascular applications - can be used for ureteral occlusion either with a latex cover [38] or as a scaffold to secure additional embolisates (coils and/or glue) [24, 25, 39, 40].

Schild and associates were the first to perform ureteral occlusion using latex-covered AVPs (Type II) in 2009 [41]. The procedure is performed via a $12 \mathrm{~F}$ nephrostomy access. Before the deployment catheter is advanced into the ureter, a sterile latex finger stall is placed around the distal tip and fastened with nonabsorbable suture material. When the AVP is advanced out of the sheath, the latex cover is pressed to the ureteral wall leading to immediate and complete occlusion ( $\triangleright$ Fig.5). In a subsequent study by Pieper et al., 9/10 ureters remained completely occluded until the patient's death or surgical explantation (mean follow-up: 161 days; range: $10-462$ days). Dislocation of the latex finger stall during implantation was encountered in the remaining one ureter, which lead to reduction of urinary flow, but without total occlusion. An expected inflammatory reaction of the ureteral wall as previously described by Bing et al. [2, 42] did not lead to sec- 

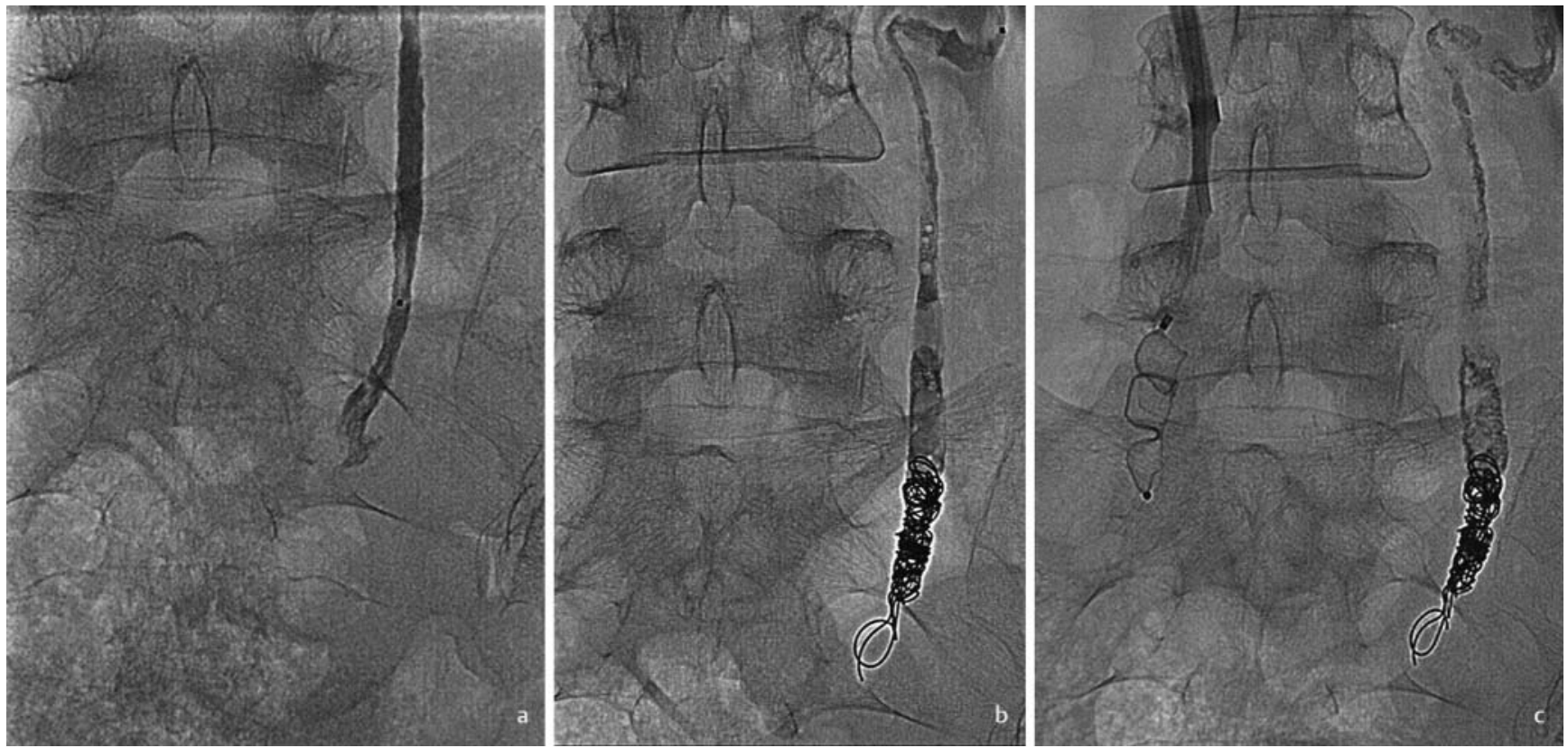

- Fig. 4 Ureteral occlusion in the same patient as shown in $>$ Fig. 1. Due to severe kinking, the distal part of the left ureter could only be intubated by microcatheter so that coil embolization with additional NBCA/iodized oil embolization was performed $\mathbf{a}, \mathbf{b}$. The right ureter was occluded using a latex-covered Amplatzer vascular plug c. Both ureters were permanently occluded until the patient's death 7 months later.

- Abb.4 Ureterokklusion bei der gleichen Patientin aus $>$ Abb. 1. Links konnte bei ausgeprägtem Kinking der distale Ureter nur mittels Mikrokatheter intubiert werden, so dass dieser mittels Coils und NBCA/Lipiodol embolisiert wurde a, b. Der rechte Ureter wurde mittels latexüberzogenem Amplatzer Vascular Plug okkludiert c. Beide Ureteren waren permanent bis zum Tod der Patientin 7 Monate später verschlossen.

ondary complete occlusion in this case. Additional in-vitro examinations in a porcine kidney model showed that 12 or $14 \mathrm{~mm}$ type 2 AVPs offered the best occlusive properties, withstanding even supra-physiological intra-luminal pressure levels without dislocation or leakage [38].

Other authors have raised the concern that a latex-covered AVP may dislocate and suggested using the AVP as a scaffold for additional glue embolization with high clinical success rates of $90-100 \%$ during follow-up (7 - 14 months) [24, 25, 39, 40].

A disadvantage of AVPs for ureteral occlusion is higher costs for the embolization device compared to e. g. coils or glue alone. This is especially true when employing the so-called "sandwich technique" using two AVPs to secure the glue [24].

In our experience a latex-covered AVP is superior to a combination of an AVP with coils and glue or even a second AVP due to shorter procedure times, lower costs and possible AVP extraction to allow for only temporary occlusion. However, deployment of an AVP may be technically difficult in tortuous ureters so that coil embolization may still be necessary in such cases ( $\bullet$ Fig. 4).

\section{Outlook}

Recently Kuetting et al. investigated the use of the ArtVentive EOS device, a commercially available ePTFE-covered nitinol spiral approved for endovascular embolization, for ureteral occlusion in a porcine model [43]. The results of this in-vitro study were promising as complete and immediate ureteral occlusion was achieved in all investigated porcine kidneys $(n=10)$. The occlusion devices sustained intra-ureteral pressures far greater than those to be expected in-vivo. It remains to be seen whether this "off the shelf" solution realizes the same results in in-vivo use.

\section{Conclusion}

Lower urinary tract fistulas are a rather rare, but severe condition associated with considerable morbidity. Treatment is challenging, especially in fistulas caused by pelvic malignancy or radiation therapy, and should be performed in specialized centers. Surgical treatment attempts fail in a considerable number of patients and may even be precluded altogether in severely ill patients. In order to achieve optimal treatment, interdisciplinary approaches with the involvement of urologists, gynecologists and radiologists experienced in the treatment of urinary tract fistulas are necessary.

All presented minimally invasive treatment options enable successful ureteral occlusion at a low complication rate. The adequate option should be performed according to the individual needs of the patient and the individual knowledge and experience of the treating interventional radiologist. So far, no study has proven superiority of any technique over the others. Today, primarily transrenal embolization using coils, vascular plugs or detachable balloons is in clinical use and should be in the armamentarium of interventional radiologists. Balloon occlusion and latex-covered AVPs additionally offer the prospect of temporary ureteral occlusion which may be desirable in patients with a longer life expectancy. 

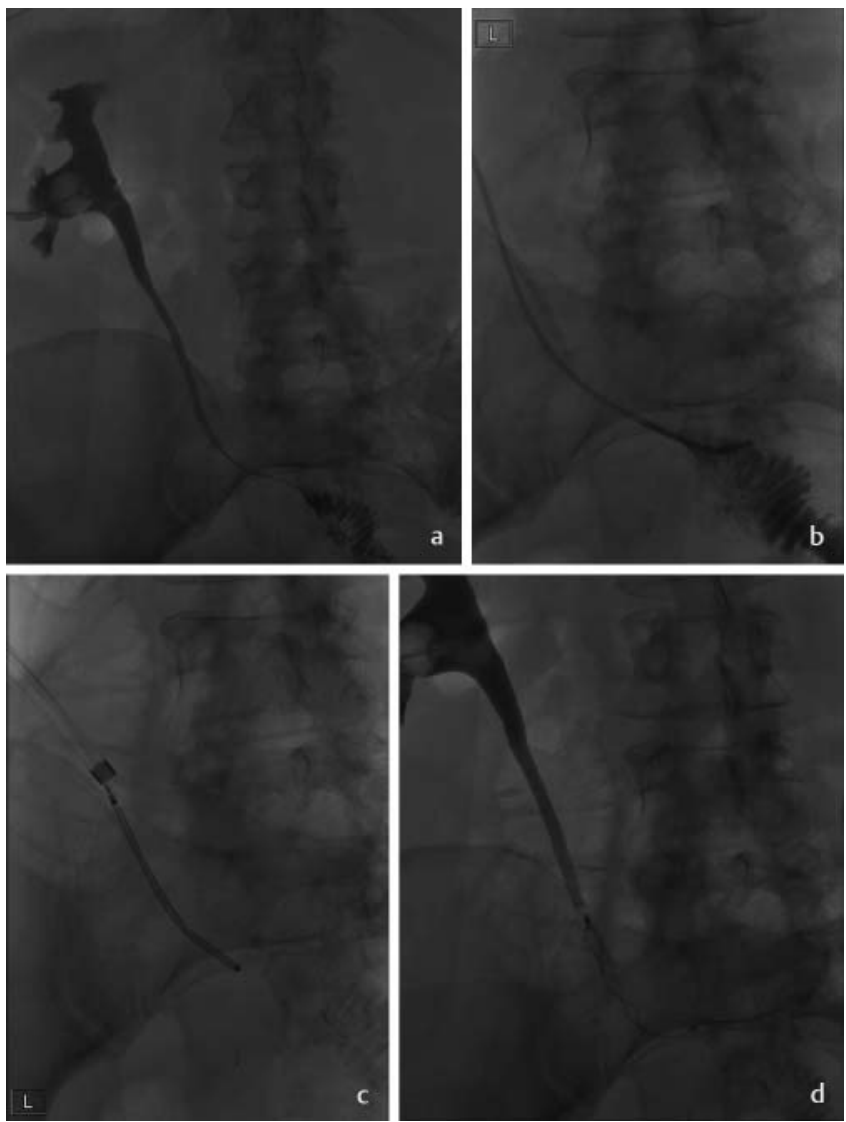

- Fig. 5 Ureteral occlusion of the left ureter (prone position) in a patient with a ureteroenteric fistula. a Ureterography via the nephrostomy tube demonstrating contrast flow from the ureter into the small bowel. $\mathbf{b}$ The site of the fistula was cannulated using a $5 \mathrm{~F}$ catheter. c Positioning of a latex-covered Amplatzer vascular plug in the distal ureter immediately proximal to the fistula. $\mathbf{d}$ Control ureterography via a new nephrostomy tube showed complete ureteral occlusion. The fistula was permanently occluded immediately after intervention (follow-up 23 months (patient's death)).

- Abb. 5 Okklusion des linken Ureters (Bauchlage) eines Patienten mit ureteroenterischer Fistel. a Die Ureterographie über das einliegende Nephrostoma zeigt den Kontrastmittelabstrom aus dem Ureter in Dünndarmschlingen. b Die Fistel wird mittels 5F Katheter intubiert. c Positionierung eines latexüberzogenen Amplatzer Vascular Plugs im distalen Ureter unmittelbar proximal der Fistel. d Die Kontrollureterographie über einen neuen Nephrostomiekatheter bestätigt eine vollständige Ureterokklusion. Die Fistel war nach der Intervention permanent okkludiert (Follow-up Zeitraum: 23 Monate (Tod des Patienten)).

\section{Conflict of Interest}

The authors declare that they have no conflict of interest.

\section{Widmung}

Diese Arbeit ist Herrn Univ.-Prof. Dr. med. Hans Heinz Schild gewidmet, bei dem wir uns herzlich für die langjährige und stete Unterstützung in allen klinischen und wissenschaftlichen Belangen bedanken möchten.

[1] Avritscher R, Madoff DC, Ramirez PT et al. Fistulas of the lower urinary tract: percutaneous approaches for the management of a difficult clinical entity. Radiographics 2004; 24 (Suppl. 1): S217-S236. doi:10.1148/ rg.24si045508

[2] Bing KT, Hicks ME, Figenshau RS et al. Percutaneous ureteral occlusion with use of Gianturco coils and gelatin sponge. Part I. Swine model. J Vasc Interv Radiol 1992; 3: 313-317

[3] Wong M], Wong K, Rezvan A et al. Urogenital fistula. Female pelvic medicine \& reconstructive surgery 2012; 18: $71-78$ quiz 78 . doi:10.1097/SPV.0b013e318249bd20

[4] Lee RA, Symmonds RE, Williams TJ. Current status of genitourinary fistula. Obstetrics and gynecology 1988; 72: 313-319

[5] Chrouser KL, Leibovich BC, Sweat SD et al. Urinary fistulas following external radiation or permanent brachytherapy for the treatment of prostate cancer. The Journal of urology 2005; 173: 1953-1957. doi:10.1097/01.ju.0000158041.77063.ff

[6] Popuri R, Zuckerman DA. Ureteral interventions. Semin Intervent Radiol 2011; 28: 392 - 395. doi:10.1055/s-0031-1296081

[7] Adler AJ, Ronsmans C, Calvert C et al. Estimating the prevalence of obstetric fistula: a systematic review and meta-analysis. BMC pregnancy and childbirth 2013; 13: 246. doi:10.1186/1471-2393-13-246

[8] Bergqvist D, Parsson H, Sherif A. Arterio-ureteral fistula-a systematic review. European journal of vascular and endovascular surgery : the official journal of the European Society for Vascular Surgery 2001; 22: 191 - 196. doi:10.1053/ejvs.2001.1432

[9] Ghali AM, El Malik EM, Ibrahim Al et al. Ureteric injuries: diagnosis, management, and outcome. The Journal of trauma 1999; 46: 150-158

[10] Yu NC, Raman SS, Patel M et al. Fistulas of the genitourinary tract: a radiologic review. Radiographics 2004; 24: 1331 - 1352. doi:10.1148/ rg.245035219

[11] Murphy JM, Lee G, Sharma SD et al. Vesicouterine fistula: MRI diagnosis. Eur Radiol 1999; 9: 1876 - 1878. doi:10.1007/s003300050939

[12] Schmeller NT, Gottinger H, Schuller J et al. Percutaneous nephrostomy as primary therapy of ureterovaginal fistula. Der Urologe Ausg A 1983; 22: $108-112$

[13] Al-Otaibi KM. Ureterovaginal fistulas: The role of endoscopy and a percutaneous approach. Urol Ann 2012; 4: 102 - 105. doi:10.4103/09747796.95556

[14] Dowling RA, Corriere JN Jr. Sandler CM. latrogenic ureteral injury. The Journal of urology 1986; 135: 912-915

[15] Hausegger KA, Portugaller HR. Percutaneous nephrostomy and antegrade ureteral stenting: technique-indications-complications. Eur Radiol 2006; 16: 2016-2030. doi:10.1007/s00330-005-0136-7

[16] Farrell TA, Wallace M, Hicks ME. Long-term results of transrenal uretera occlusion with use of Gianturco coils and gelatin sponge pledgets. J Vasc Interv Radiol 1997; 8: 449-452

[17] Moldwin RM, Smith AD. Percutaneous management of ureteral fistulas. The Urologic clinics of North America 1988; 15: 453-457

[18] Cragg AH, Castañeda F, Amplatz K et al. Percutaneous Ureteral Clipping: Technique and Results. Semin intervent Radiol 1989; 6: 176-181. doi:10.1055/s-2008-1075913

[19] Darcy MD, Lund GB, Smith TP et al. Percutaneously applied ureteral clips: treatment of vesicovaginal fistula. Radiology 1987; 163: 819-821. doi:10.1148/radiology.163.3.3575736

[20] Farrell T, Yamaguchi T, Barnhart W et al. Percutaneous ureteral clipping: long-term results and complications. J Vasc Interv Radiol 1997; 8: $453-456$ 
[21] Reddy PK, Moore L, Hunter D et al. Percutaneous ureteral fulguration: a nonsurgical technique for ureteral occlusion. The Journal of urology 1987; 138: $724-726$

[22] Kopecky KK, Sutton GP, Bihrle R et al. Percutaneous transrenal endoureteral radio-frequency electrocautery for occlusion: case report. Radiology 1989; 170: 1047 - 1048. doi:10.1148/radiology.170.3.2916055

[23] Gunther R, Marberger M, Klose K. Transrenal ureteral embolization. Radiology 1979; 132: 317 -319. doi:10.1148/132.2.317

[24] Saad WE, Kalagher S, Turba UC et al. Ureteric embolization for lower urinary tract fistulae: use of two amplatzer vascular plugs and N-butyl cyanoacrylate employing the "sandwich" technique. Cardiovasc Intervent Radiol 2013; 36: 1068 - 1072. doi:10.1007/s00270-012-0510-1

[25] Shabrang C, Kelbach SM, Hsu DP et al. Therapeutic ureteral occlusion with n-butyl cyanoacrylate glue and an AMPLATZER plug scaffold. J Vasc Interv Radiol 2012; 23: 428-430. doi:10.1016/j.jvir.2011.12.009

[26] Schild H, Voges G, Gunther R et al. Percutaneous ureteral occlusion. Methods, results, problems. Rofo 1991; 154: 531 - 534. doi:10.1055/s2008-1033179

[27] Gunther R, Klose K, Alken P. Transrenal ureteral occlusion with a detachable balloon. Radiology 1982; 142: 521 - 523. doi:10.1148/radiology.142.2.7054847

[28] Gunther RW, Klose KJ, Alken P et al. Transrenal ureteral occlusion using a detachable balloon. Urologic radiology 1984; 6: 210-214

[29] Papanicolaou N, Pfister RC, Yoder IC. Percutaneous occlusion of ureteral leaks and fistulae using nondetachable balloons. Urologic radiology 1985; 7: $28-31$

[30] Schild HH, Gunther R, Thelen M. Transrenal ureteral occlusion: results and problems. J Vasc Interv Radiol 1994; 5: 321 - 325

[31] Marr B, Wright KC, Carrasco CH et al. Experimental evaluation of a new device for percutaneous transrenal ureteral occlusion. J Vasc Interv Radiol 1997; 8: 775-780

[32] Franke M, Winand S, Chang DH et al. Urinary Tract Fistulas: Transrenal Reversible Ureteral Occlusion With Detachable Semicompliant Balloons. Urology 2015; 86: 388 - 393. doi:10.1016/j.urology.2015.03.042

[33] Horenblas S, Kroger R, van Boven E et al. Use of balloon catheters for ureteral occlusion in urinary leakage. European urology 2000; 38: 613 617. doi:20340
[34] Kinn AC, Ohlsen H, Brehmer-Andersson E et al. Therapeutic ureteral occlusion in advanced pelvic malignant tumors. The Journal of urology 1986; 135: 29-32

[35] Gaylord GM, Johnsrude IS. Transrenal ureteral occlusion with Gianturco coils and gelatin sponge. Radiology 1989; 172: 1047-1048. doi:10.1148/172.3.1047

[36] Shindel AW, Zhu H, Hovsepian DM et al. Ureteric embolization with stainless-steel coils for managing refractory lower urinary tract fistula: a 12-year experience. BJU international 2007; 99: 364-368. doi:10.1111/ j.1464-410X.2006.06569.x

[37] Asvadi NH, Arellano RS. Transrenal Antegrade Ureteral Occlusion: Clinical Assessment of Indications, Technique and Outcomes. The Journal of urology 2015; 194: 1428 - 1432. doi:10.1016/j.juro.2015.02.2964

[38] Pieper CC, Schild HH. In vitro evaluation of the occlusive properties of latex-covered amplatzer vascular plugs for transrenal ureteral occlusion. Journal of endourology 2014; 28: 708 - 716. doi:10.1089/ end.2014.0088

[39] Pieper CC, Meyer C, Hauser S et al. Transrenal ureteral occlusion using the Amplatzer vascular plug II: a new interventional treatment option for lower urinary tract fistulas. Cardiovasc Intervent Radiol 2014; 37: 451 457. doi:10.1007/s00270-013-0662-7

[40] Grasso RF, Cazzato RL, Luppi G et al. Bilateral transrenal ureteral occlusion by means of n-butyl cyanoacrylate and AMPLATZER vascular plug. The Indian journal of radiology \& imaging 2014; 24: $129-131$. doi:10.4103/0971-3026.134390

[41] Schild HH, Meyer C, Mohlenbroch M et al. Transrenal ureter occlusion with an Amplatzer vascular plug. J Vasc Interv Radiol 2009; 20: 1390 1392. doi:10.1016/j.jvir.2009.06.032

[42] Bing KT, Hicks ME, Picus D et al. Percutaneous ureteral occlusion with use of Gianturco coils and gelatin sponge. Part II. Clinical experience. J Vasc Interv Radiol 1992; 3: 319 - 321

[43] Kuetting D, Meyer C, Schild HH et al. In Vitro Evaluation of the Occlusive Properties of the ArtVentive Endoluminal Occlusion System Occlusion Device for Transrenal Ureteral Occlusion. Journal of endourology 2017. doi:10.1089/end.2017.0493 